Accepted refereed manuscript of:

Londoño-Roldan JC, Elms J \& Davies K (2016) Conceptualising and measuring consumer-based brand-retailer-channel equity, Journal of Retailing and Consumer Services, 29, pp. 7081.

DOI: 10.1016/i.jretconser.2015.11.004

(C) 2016, Elsevier. Licensed under the Creative Commons AttributionNonCommercial-NoDerivatives 4.0 International http://creativecommons.org/licenses/by-nc-nd/4.0/ 


\section{Conceptualising and Measuring Consumer-Based Brand-Retailer-Channel Equity}

Juan Carlos Londoño Roldan (Corresponding Author)

School of Business Administration

Pontificia Universidad Javeriana Cali

Cali, Colombia

Email: juanclondono@javerianacali.edu.co

Jonathan Elms

Massey Business School

Massey University

North Shore, Auckland 0745

New Zealand

Email: j.r.elms@massey.ac.nz

\&

Keri Davies

Institute for Retail Studies

Stirling Management School

Stirling University

Stirling, FK9 4LA

United Kingdom

Email: b.k.davies@stir.ac.uk

\section{Author biographies}

Juan Carlos Londoño is assistant professor at Pontificia Universidad Javeriana in Cali, Colombia. Currently researches topics in consumer behaviour and retailing. Specifically, multichannel retailing, package design, brand image transference and shopping list experience.

Jonathan Elms is the Sir Stephen Tindall Chair in Retail Management at Massey Business School, Massey University. His research interests encompass retailing and consumer behaviour. More specifically, this includes retail change (particularly in relation to consumer choice and public policy debates), everyday consumption practices, and shopping spaces and places.

Keri Davies is a senior lecturer based in the Institute for Retail Studies, University of Stirling. His research interests lie primarily in the areas of retailing and consumer marketing, with a particular interest in the activities of consumer co-operatives and the changes taking place in Asian retailing. 


\title{
Conceptualising and Measuring Consumer-Based Brand-Retailer-Channel Equity
}

\begin{abstract}
This paper presents a critical review and synthesis of the extant literature which underscores the complexities of conceptualising and measuring the synergies created by brand, retailer, and channel equity. To this end, the concept of Consumer-based Brand-Retailer-Channel Equity (CBBRCE) is developed. The concept and its measurement are subsequently tested empirically using survey data and structural equation modelling with path-PLS. The results confirm that CBBRCE is created by CBBRC Awareness, Quality and Loyalty. Additionally, there is evidence of a connection between CBBRCE and intention. The paper concludes with a discussion of the managerial implications of CBBRCE, and signals areas for further academic research.
\end{abstract}

Key Words: Brand Equity, Retailer Equity, Channel Equity, CBBRCE, Path-PLS. 


\section{Introduction}

Brands have long been seen as a source of differentiation (Aaker, 1996). The development of manufacturer and store brands, the latter reflecting the increasing power and influence of retailers (Dawson et al., 2008), and the growing importance of non-store channels such as the internet (Dennis, Newman et al, 2010), have led not only to increased value for the consumer but also to a growing tension between product managers and retailers. However, the complex interplay between manufacturers' brands, retailers, and channels from the consumers' perspective has largely been underplayed in existing conceptualisations and measurements of brand equity. Firms that can provide evidence of such synergies could derive and harness financial rewards (Teller and Reutterer, 2008); for example, it has been shown that consumers seek brands with congruent personalities (Garsvaite and Caruana, 2014). Manufacturers could also benefit from an understanding of which retailers and channels contribute most to the equity of their brands; conversely, retailers could benefit from a tool that enables them to determine what manufacturer brands distributed through which channels create more equity for their business in the long term (Keller and Lehmann, 2009).

Accordingly, the aim of this paper is threefold. First, to develop a holistic conceptual model that captures the synergies created by the interactions between brands, retailers, and channels; second, to provide empirical evidence that tests the conceptual model and its measurement, and; finally, to evaluate the application of the proposed model from both the perspective of the manufacturer and the retailer. The remainder of the paper is structured as follows. Building on the seminal work of Aaker (1991), a critical review and synthesis of the extant brand, retailer, and channel equity literatures are described and discussed. This is followed by the introduction of the concept of Consumer-Based Brand-Retailer-Channel Equity (CBBRCE) that captures the synergies created by brand, retailer, and channel equity. The methodology and then the 
results of the evaluation of CBBRCE measurement are presented and discussed. The paper concludes with a discussion of the managerial implications of CBBRCE, signals the limitations of the current research, and presents an agenda for further academic studies.

\section{Literature Review}

In this paper, Aaker's brand equity model (1991) is extended to create CBBRCE for the following reasons: 1) it provides a consumer-focussed perspective on brand equity; 2) it contains the loyalty dimension, which has been proven to be an important measure in the examination of the brand-retailer association; 3) it has been widely accepted and implemented by both branding and retailing academics; 4) it has been successfully operationalised; 5) it has an explicit link to purchase intention; 6) it is simple and parsimonious, and; 7) it is accurate to represent the memory/cognitive associations formed by consumers. The implications of such are now described and discussed.

Although there is no universal definition and measurement of brand equity, the models set out by Aaker (1991; 1996) and Keller (1993) have been extensively employed. Aaker’s framework in particular has been widely accepted and empirically tested (Cobb-Walgren et al. 1995; Yoo and Donthu, 1997; Motameni and Shahrokhi, 1998; Sinha and Pappu, 1998; Low and Lamb Jr, 2000; Prasad and Dev, 2000; Pappu, Quester et al. 2005).

\section{INSERT TABLE 1 ABOUT HERE}

The comprehensive review of the studies presented in Table 1 underscores that the majority the extant literature focusses on product-level brand equity, followed by a smaller amount of research that has concentrated on retailer equity, with even less has been devoted to channel equity, as discussed below. 


\subsection{Brand Equity}

Despite the growing academic and commercial interest in brand equity (for a review, see Feldwick, 1996; Christodoulides and De Chernatony, 2010), there is still little consensus concerning what is encompassed by the concept and, as such, how it should be measured (Keller, 2003; 2010; Ahmad and Thyagaraj, 2014). Studies on brand equity follow either a financial perspective (e.g. Farquhar et al., 1991; Simon and Sullivan, 1993; Haigh, 1999; Thuy et al., 2013) or a consumer/customer-based perspective (e.g. Aaker, 1991; Keller, 1993); 1993; Yoo and Donthu, 2001a; Vazquez et al., 2002; Kakati and Choudhury, 2013). The most salient dimensions discussed in the extant literature appear to be brand associations/image, brand awareness, perceived quality and brand loyalty. The majority of this research is based on the seminal work of Aaker (Ailawadi et al., 2003), which defines brand equity as 'the marketing effects or outcomes that accrue to a product with its brand name compared to those that would accrue if the same product did not have the brand name’ (Aaker, 1991).

Whilst Aaker's definition of brand equity does not explicitly recognise the interaction between brands, retailers, and channels, it does however have scope for expansion. The 'brand associations' construct has been recognised as a core asset for building strong brands (Chen, 2001). Already including organisational associations, through co-branding alliances, brand cocreation, and networks (Rao and Ruekert, 1994; Washburn et al., 2004; Simonin and Ruth, 1998a; Hatch and Schultz, 2010), it has the potential to be extended further to include associations generated by the interactions between brand, retailer, and channel equity. These areas have been highlighted in studies focussing on online retail/service (ORS) brand equity (Christodoulides and De Chernatony, 2004), as well as research conducted on the evolution of branding in a multi-channel environment (Leone et al., 2006; Keller, 2010; Ansari et al., 2008). 
Co-branding creates synergies through the complementary nature of the brands that are combined (Richelieu et al., 2011). Park et al (1996) suggest that co-branding creates a higher quality perception about a new product than each constituent brand does. A 'spillover' effect occurs when co-branding creates positive attitudes towards the two individual partner brands (Simonin and Ruth, 1998b). Part of the value a company can create is added by partners such as channel members and by co-branding (Srivastava et al., 1998). The concept of cobranding is defined as 'a form of cooperation between two or more brands' (Leitch and Davenport, 2007); a branding strategy which is popular in consumer products that pairs two or more branded products to form a separate and unique product (Park et al., 1996). However, this definition would not be precise to describe the union between a manufacturer brand, a retailer brand, and a channel, because there is no product created: it is more a particular entity or experience. Wright and Clarke’s (2014) case study of the Retail Food Group underscores the need to extend the concept of co-branding to cover retail co-branding initiatives. Moreover, retailer-manufacturer brand alliances have an impact on both retailer equity and manufacturer brand equity (Arnett et al., 2010), therefore attributing the benefit of the alliance to either of them would be unmerited.

Whilst, as noted earlier, extensive research has been conducted on the concept of brand equity, the literature that has examined retailer equity is scarce (Tran, 2006), and even less attention has been given to channel equity. The resulting synergistic effects and interrelationship between branded products, retailers and channels therefore remain underplayed.

\subsection{Retailer Equity}

Although it is clear that retailers are brands, the measurement of their equity has been treated differently: as retailer equity. The rise of the retailer as a brand is one of the most important 
trends in retailing (Grewal et al., 2004). Retailer brands are sufficiently different from product brands. Retailer brands are typically more multi-sensory in nature than product brands, and can rely on rich consumer experiences to impact their equity (Ailawadi and Keller, 2004). Successful retail branding can be extremely important in helping influence consumers' perceptions and influence store choice and loyalty (Ailawadi and Keller, 2004). Customerbased retail brand equity involves a "shortcut" in the minds of consumers that recalls from memory the most salient positive elements of satisfaction with past shopping experiences and goods purchased, which in turn influences future patronage and minimises the potential influence of competitor efforts (Ailawadi and Keller, 2004). In most consumer industries, the image and equity of retailer brands also depends on the manufacturer brands they carry and the equity of those brands. Retailers use manufacturer brands to generate consumer interest, patronage, and loyalty in a store (Ailawadi and Keller, 2004).

Retailer equity is defined by Arnett et al., (2003) as a set of brand assets and liabilities linked to a store brand (e.g., Wal-Mart), its name and symbol, that adds to or subtracts from the perceived value of the store brand by its consumers (both actual and potential). The value of the store as a brand is the focus in this definition; the manufacturer's brand is neglected. Research on retailer equity resonates with the literature on brand equity in respect to its diversity and lack of common grounds, with the majority of such studies investigating either store image (see, Jinfeng and Zhilong, 2009), perceived quality and/or brand awareness. This literature does, however, signal two possible approaches that could be used to examine retailer equity. The first is to analyse retailer equity from the point of view of retail managers (Baldauf et al., 2003; 2009); the second is more consumer-centric analysis, including the development of 'Retailer Equity Indexes'. The current research advocates the latter given findings from Jara (2009) who indicates that the personality of the retail brand could be used by marketers to 
maximise the potential value of their brands and to position them on a larger set of associations. Of particular interest is the suggestion of the potential synergies that can be created by the brand-retailer interaction.

Research has also highlighted that retailers and manufacturers can create synergies by working together (Anderson and Narus, 1990; Narus and Anderson, 1986). Brodie et al (2002) attempted to articulate this collaborative effort using the term 'marketplace equity'. However, marketplace equity lacks the consumers’ perspective since it is more financially driven. Others researchers have described how brand equity can be built and managed between manufacturers and retailers (e.g. Tran and Cox, 2009), but these efforts have been in a business-to-business rather than business-to-consumer context. Nevertheless, such research can aid manufacturers and retailers to consider to what extent their brand equity alliances are successful. For example, Yoo et al. (2000) incorporate elements of channel and store image into the measurement of brand equity as antecedents of Aakers’ (1991) brand equity dimensions.

\subsection{Channel Equity}

A channel is a two-way interactive process between the customer and the firm. During this process, the customer is not receiving information passively, but rather is interacting with the channel. A store, a retailer's website, a catalogue, the use of a sales force, a third party agency, and a call centre, are all examples of channels. Television advertising was not considered a channel for the purposes of this article. Sissors and Bumba (1996) defined television as a class of media, that also include, for example, newspapers, magazines, direct mail, radio, television, and billboards, which are used to convey a message to the public. The purpose of channels is to deliver entertainment or information, communicate marketing activities, facilitate the use of the products or services purchased, or build relationships with customers. A marketing channel 
is a set of independent organisations performing all of the functions necessary to make a product available (Zhuang and Zhou, 2004).

A retail channel can be a brand differentiator (Rastogi and Sharma, 2015), and is in urgent need of an effective and efficient performance evaluation system (Rastogi and Sharma, 2015). Although studies have shown the impact of both product brand image and online store image on consumer behaviour (Aghekyan-Simonian et al., 2012), there is need to measure companies that are delivering a multi-channel brand experience in which the channels are mutually supportive (Rowley, 2009). Researchers admit that there are synergies created and designed between the firm and channels, but little is done to capture the effects (Neslin et al., 2006).

Channel equity can be defined 'as the net present value of the current and future profits generated through a distribution channel' (Sullivan and Thomas, 2004). The few studies that examine channel equity tend to emphasise a business-to-business view of channel relations; whereas channel equity concerns the effects of relational ties in inter-organisational exchanges (Davis and Mentzer, 2008), e.g. channel equity with retailers (Bick, 2009). Channel equity thus omits the role of the brand in influencing the channel and vice versa (Jones, 2005). Accordingly, channel equity is considered as a firm’s resource (Varadarajan and Yadav, 2002), from which brands can benefit or be leveraged (Uggla, 2004). Channels can also impact consumers' perceptions of fairness and the price of a product (Choi and Mattila, 2009), and provide additional benefits, including: lower costs, price premiums, the construction of competitive barriers, satisfied buyers, and facilitates the trial of brand and category extensions (Srivastava et al., 1998). It has also been suggested that channel equity, together with brand equity and firm equity, are antecedents of relationship intention (Kumar et al., 2003). 


\section{Consumer-Based Brand-Retailer-Channel Equity (CBBRCE)}

Given the limitations of the extant literature, as discussed above, we introduce the concept of Consumer-Based Brand-Retailer-Channel Equity (CBBRCE). In accordance with Aaker's (1991) conceptualisation of brand equity, we define CBBRCE as 'a set of assets and liabilities created by the link among the brand, the retailer and the channel, its names and symbols that add to or subtract from the value provided by a good or service (or a combination thereof) to its customers (both actual and potential)'. The fundamental assumption of the CBBRCE is that value is generated by the end consumer, whereby equity is a holistic evaluation of the value generated by the combination of the brand, retailer and channel.

Incorporating elements of brand, retailer and channel into Aaker's four main brand equity dimensions results in the following definitions:

- Brand-Retailer-Channel Perceived quality is defined as the 'perception of the overall quality or superiority of a brand-retailer-channel with respect to its intended purpose relative to alternatives’ (Aaker, 1991).

- Brand-Retailer-Channel Consumer Loyalty is defined as consumers' 'deeply held commitment to re-buy or re-patronize a preferred brand-retailer-channel consistently in the future, despite situational influences and marketing efforts having the potential to cause switching behaviour' (Dietz, 1997).

- Brand-Retailer-Channel Awareness is defined as the 'ability to recognize or recall that a brand is sold in certain retailer and is part or member of a specific channel' (Aaker, 1991).

- Brand-Retailer Channel Associations is defined as the 'ability to recognize or recall a brand sold in certain retailer as part or member of a specific environment or channel' (Aaker, 1991). 
The conceptual model that illustrates the proposed relationships is presented in Figure 1.

\section{INSERT FIGURE 1 ABOUT HERE}

The proposed CBBRCE concept works better for hypermarkets, supermarkets or large stores that carry brands, and are looking for associations with these brands, but it can also include other type of retailers, as well as services. For example MacDonalds has brand alliances with Coca-Cola, H\&M with Versace, IKEA with Nissan, and AVON with Korres.

\subsection{Selection of Intention Measurements}

The method of generalised intention was selected to measure intention. The items used were: 'I expect'; 'I want'; and 'I intend'. The use of these items has been consistently supported in the extant literature (Armitage and Conner, 2001).

See Appendix A for a list of items proposed for measurement and Appendix B for the actual items used in the study.

Adopting Aaker's approach, and with reference to the literature presented in Table 1, the following five main hypotheses were formulated.

H1. BRC Awareness positively and directly influences the creation of CBBRCE.

H2. BRC Quality positively and directly influences the creation of CBBRCE.

H3. BRC Loyalty positively and directly influences the creation of CBBRCE.

H4. BRC Quality positively and directly influences the creation of CBBRCE.

H5. CBBRCE positively and directly influences the creation of intention.

\subsection{The holistic consumer}


From the perspective of how consumers analyse information, this research relies on the Information Integration Theory, which assumes that consumers utilise information from a number of sources to make an overall judgment (Anderson, 1976). The 'spillover’ effect created by Brand-Retailer-Channel can be explained with the Attitude-Transfer model which suggests that when an extension fits with the brand, a consumer's attitude toward the brand will transfer to his or her attitude toward the extension (Aaker and Keller, 1990). It is proposed that this 'transfer effect' can also occur from brands to retailers to channels.

The current research adopts a cognitive approach, rooted in Associative Network Theories, that are concerned with the organisation of human semantic memory (Till et al., 2011; Collins and Loftus, 1975; Chen, 2010). To be able to rate the attitudes towards a brand-retailer-channel, this study used verbal stimuli to represent consumer judgments (Holbrook and Moore, 1981). The use of verbal stimuli promotes analytical and in-depth evaluation of choice alternatives (Tversky, 1977). Verbal stimulus forces the consumer to add pros and cons to determine the highest value (Chen, 2010). This research is underpinned by the assumption that decision makers are 'rationally bounded' (Simon, 1972), and that rationality is expected as 'consumers need to find out about brands, channels, and place before buying a product' (Janakiraman and Niraj, 2011). Consumers develop choice criteria before making a purchase decision (Yasin et al., 2007). Although Gestalt Theory confirms that consumers think in a configural/holistic/additive way (Holbrook and Moore, 1981), the gestalt has, however, been criticised for being descriptive rather than explanatory (Hilligsoe, 2009), and therefore not adopted in the current research. Anderson (1971) and Troutman and Shanteau (1976) demonstrated that consumers evaluate products by averaging information and not by adding. However, averaging has been challenged on methodological grounds and not used in this study. 
Neuromarketing research has shown that including hints of benefits in the products' name influences purchase decisions (Hillenbrand et al., 2013). In this study, the benefits of a particular channel and retailer are included as part of the evaluated product's name. Recent studies have found that the retail framework is important for brands. Various elements of the retail framework can have a significant effect on the value that brands have within that framework (Dabija et al., 2014).

Rational versus emotional is a common dichotomy in psychology literature (Frank et al., 2009) that has been confirmed by psychological and neuroimaging studies (Breckler and Wiggins, 1989; Frank et al., 2009). Unfortunately, extant brand equity measurement discloses the brand of the product being evaluated, and hence makes the consumer respond to direct questioning as a way to evaluate equity. This way of asking captures the rational aspect of the relation while the emotional is underestimated. This study follows a rational approach to link the brand, retailer, and channel. Considering the impact that emotions could potentially have on equity, this study explored adding two variables to the model: anticipated negative emotions and positive emotions. The results of this did not show significant results on CBBRCE.

\section{Method}

This research is part of a larger study that compared purchasing decisions in single and multichannel retail environments. The survey instrument incorporated 16 items found in the literature, and are illustrated in Table 1. The selected items followed the same structure proposed by Yoo and Donthu (2001b) who tested the measurement of brand equity and followed by several marketing researchers (Cobb-Walgren et al., 1995; Sinha and Pappu, 1998; Washburn and Plank, 2002b; Yoo and Donthu, 2002). 


\section{INSERT TABLE 2 ABOUT HERE}

To evaluate the proposed model, the study used a hair loss product called Regaine (Rogaine in the U.S.). Regaine is a market leader in the hair loss products category (Propeciasexualsideffects.com n.d.). This facilitates the evaluation of attributes (Day, 1972). The retailer selected was Boots (a well-known UK retailer with a well-known website). Regaine has a brand alliance with Boots such that Regaine television commercials remind consumers that the product is available at Boots. Regaine is a product targeted mainly at men (Dennis et al., 2010). These characteristics created the need for a male sample. This is an advantage versus other studies in brand equity research which tend to use student samples. The data was collected from a group of men aged between 18 to 65 years who lived in or around two urban cities with a population of more than 20,000 inhabitants in Scotland. Any man is susceptible to lose his hair, therefore, all men were considered as potential Regaine users. A sample was selected for this study. Data was collected from two barbershops. Every consumer who had to wait for a haircut was approached to answer the survey. The survey produced a sample size of 60 respondents from the internet channel, 60 more were included from the drugstore and 60 from multi-channel for a total of 180 responses.

Confirmatory Factor Analysis (CFA) was used to test the structural equation model. CFA evaluated the measurement consistency and the construct relationships. Loadings were evaluated in order to assess the outer model. Standardised indicator loadings should be greater than or equal to 0.7. The software used to represent and test this model was Smart PLS 3.0 (Ringle et al., 2014). The software default settings were selected. PLS minimal sample size recommendation ranges from 30 to 100 cases (Chin, 2010) making of PLS an adequate tool for this study. Fit indexes were not included because PLS does not have a covariance reproduced 
matrix such as the one produced by Lisrel or AMOS, therefore, it does not produce fit indexes like RMSEA or GFI. A simulation performed by Henseler and Sarstedt shows that the GoF and the $\mathrm{GoF}_{\mathrm{re}}$ are not suitable for model validation (Henseler and Sarstedt, 2013). Of the original pool of 16 items proposed, CBBRCE1, and LOY1 were dropped to meet the loading requirements from the multi-channel sample.

\section{Results}

Table 2 presents a summary of the main descriptive statistics. More than half of the sample was aware of the existence of Regaine: (49\%) Aware and (6.1\%) had been users. Almost 60\% were familiar with the Internet channel and the sample was balanced between married and single men. The education level was evenly distributed and the income level was mainly between $£ 10000$ and $£ 29000$.

\section{INSERT TABLE 3 ABOUT HERE}

\subsection{Step One: Measurement Model}

Brand or Retailer Equity can be modelled as either formative (Arnett et al., 2003; Herrmann et al., 2007; Jara and Cliquet, 2012) or reflective (Pappu et al., 2005; Yoo and Donthu, 2001b). In this study it was modelled in a formative way, under the assumption that there is no correlation between awareness, quality and loyalty. The first step of the two-step analysis involved the evaluation of the measurement model or the outer model. A Confirmatory Factor Analysis (CFA) evaluated the measurement model. The CFA confirmed the reliability and validity of the reflective scales. A graphic representation of the conceptual model is presented in Figure 2.

\section{INSERT FIGURE 2 ABOUT HERE}

Figure 2 also illustrates the inner and outer model relationships. The figure represents the indicators and latent variables that were used in the study. Loadings were evaluated in order to 
assess the outer model. Standardised indicator loadings should be greater than or equal to 0.7. Table 3 presents the quality criteria for the model. The loadings, AVE and CR were all above the minimum levels. Convergent validity was achieved. The loadings in this study ranged from 0.44 to 0.98 , showing an adequate level of convergent validity. The t-statistics for the outer loadings of this study were all found to be highly significant.

\section{INSERT TABLE 4 ABOUT HERE}

Discriminant validity was analysed. The square root of the AVE (the correlation of each variable with itself) and the correlation between the reflective constructs with each other were compared. In each case, the square root of the AVE (diagonal elements) was greater than offdiagonal elements in the same row and column (Chin, 1998; Grégoire and Fisher, 2006). This result suggests that the study achieved good discriminant validity. Table 4 presents the interconstruct correlation results for the model. The correlation of each variable with itself in the three channels ranged from 0.71 to 0.93 .

\section{INSERT TABLE 5 ABOUT HERE}

Discriminant validity was also evaluated at the item level. The procedure used to evaluate discriminant validity at the item level was to compare the loadings of the item with its own construct versus its cross-loadings with other variables. All the items loaded strongly, as illustrated in Table 5.

\section{INSERT TABLE 6 ABOUT HERE}

\subsection{Step Two: Structural Model Evaluation (Inner Model)}

The significances were calculated using the bootstrap approach with 5000 re-samples. Chin (1998) and Falk and Miller (1992) suggest that the variance explained $\left(\mathrm{R}^{2}\right)$ should be greater 
than 0.1. The $\mathrm{R}^{2} \mathrm{~s}$ achieved high variance explained scores. All were above the 0.1 recommended levels for CBBRCE. However, the $\mathrm{R}^{2}$ statistics were not significant to explain intention as shown in Table 6.

\section{INSERT TABLE 7 ABOUT HERE}

\subsection{Analysis of Significances and Coefficients}

The significance of the hypothesis tested was evaluated using the bootstrap approach. Table 7 presents the coefficients and significances of the evaluated paths.

\section{INSERT TABLE 8 ABOUT HERE}

\section{Discussion}

The results strongly support the hypothesis that CBBRCE is explained by Awareness/Associations, Loyalty and Quality. The high significance and low error of the results in each of the proposed hypotheses provides evidence of the existence of this connection. All the hypotheses were accepted. The positive influence of BRC Awareness, Quality and Loyalty on CBBRCE was proven. However, a positive and direct influence of CBBRCE on intention was not demonstrated. The results confirmed that each of Aaker's (1996) dimensions added valuable information to explain the creation of CBBRCE.

The current study confirmed that it is possible to extend the basic Aaker and Keller dimensions to a broader realm, one that is able to include the synergies created by brands, retailers and channels. This study also evidenced the difficulties in unifying awareness and associations in the same construct. The problem occurs because it is possible that the levels of awareness of the brand and the retailer are dissimilar. In this case, Boots was very popular but Regaine was 
unknown for some consumers. This created inconsistencies for the scale. Therefore, it would be important to know if this problem persists when both the retailer and the manufacturer's brand are well known to consumers. The present study also benefits from the use of a nonstudent sample.

The brand-retailer-channel link can strengthen or weaken the performance of both the product brand and the retailer. The relationship between manufacturers and retailers should be viewed as a partnership instead of a competition for consumer loyalty (Narus and Anderson, 1986). The increase in the relative weight of retailers and channels in the decision of what brand and where to buy it, signals the need for extended versions of brand equity that incorporates the added value of brands, retailers and channels. The synergy resulting from integration and coordination of multiple channels is considered one of the major challenges and opportunities of multichannel management (Neslin et al., 2006). This research contributes by highlighting the distribution channel, an invisible element that often drives brand success (Davidson, 1998). CBBRCE is a first step in this broader view of brand equity; a brand equity that is able to be extended into other domains, a concept that provides a space for the synergies created by brands and retailers in the rapidly evolving multichannel context. Some manufacturers tend to focus on building strong brand associations in consumers' minds. They do this in order to control or buffer themselves from the growing power and influence of retailers in the marketplace (Tran and Cox, 2009) and the retailers' efforts to extend their brands (Mitchell and Chaudhury, 2014). Considerations of power should not prevent both parties from working together to build CBBRCE, a valuable asset for both parties (Kirk et al., 2013). The summated value resulting from brand-retailer channel interactions can result in a competitive advantage that benefits both manufacturers and retailer. However, a boundary line that shows when the association between retailers and manufacturers is detrimental for one or both parties is also needed. Independent 
measures for both retailers and manufacturers could be added to identify if one of the parts is providing most of the equity.

\subsection{Managerial Implications}

Both brand managers and retailers can use CBBRCE in several ways. CBBRCE can be used as a benchmarking tool. For example, a brand can compare its CBBRCE when stocked by different retailers. Differences in CBBRCE will indicate the competitive advantage or disadvantage of a certain brand on offer by a particular retailer and indicate if the manufacturer and retailer need to work more closely to improve their brand-retailer-channel equity. CBBRCE could also be used to help to evaluate or identify untapped market segments. For example, retailers could work together with manufacturers to measure the degree to which they have more or less common CBBRCE among consumers that are not currently targeting. CBBRCE could be used to identify in which of the five brand equity dimensions a joint effort between manufacturer and retailer should be focussed. CBBRCE could measure the additional equity generated by a new channel (such as a website) created in alliance between a retailer and a manufacturer. Furthermore CBBRCE also has the potential to be used a tool capable of demonstrating the advantages of cooperative advertising or the benefits of co-branding that can be achieved with the sponsorship of an event.

Most product offerings have to be marketed (and delivered) with at least some level of participation from an external channel (Leone et al., 2006). However, potential problems can arise as with any other brand equity measurement. For example Aaker (1996) calls attention to the loyalty dimension (does not apply to non-consumers of a brand); the perceived quality dimension (should involve a frame of reference and may not be a relevant in some contexts); and the awareness dimension (can be difficult to measure and cannot be separated from 
symbols). Furthermore, category management could be a catalyser in the future application of CBBRCE. Brand captains are usually highly recalled and recognised brands that already have started a collaborative agreement with the retailer. Relationships with high CBBRCE are needed to build traffic and profit for retailers and manufacturers.

\section{Limitations and Directions for Future Research}

The present research focuses on the core/primary dimensions of CBBRCE and as such additional research that helps to examine and explain the antecedents of CBBRCE is warranted. Some researchers have proposed marketing mix variables as antecedents of brand equity (Yoo et al., 2000; Baldauf et al., 2009) and these could be explored in future studies. However, in a CBBRCE context, using marketing mix variables as an antecedent creates problems. For example, which factors should be examined? Should the marketing mix of the retailer or the mix of the manufacturer be of concern? Experiments that manipulate marketing mix variables and evaluate the effects on CBBRCE are therefore needed. Co-branding alliances could be studied using the CBBRCE framework as a means to understand the dynamics and gains for both manufacturers and retailers. Rao defines brand alliances as 'all circumstances in which two or more brand names are presented jointly to the consumer' (Rao et al., 1999), and the brand-retailer link could be seen as an alliance between the product brand and the store brand. This paper has proposed items that are very general and serve most retailers and brands, but researchers that are interested in measuring specific retailers or brands can add items that capture specific retailer-brand associations. Studies that compare the CBBRCE across channels (online versus stores versus mobile) would provide additional insights into the gains that collaboration strategies can introduce to multi-channel environments. Research that adapts the CBBRCE to different retail formats could also help illustrate the advantages of having certain products/brands in some formats and not in others. CBBRCE can also be converted into a 
CBBRCE Index; this will provide retailers and manufacturers with the possibility of gaining knowledge and evidence base that builds on the findings of Arnett's (2003) Retail Equity Index.

Future research should also examine how CBBRCE is able to predict intention in the case of other products, behaviours, and countries. Moreover, CBBRCE should be tested in cases of products that are well known by consumers, and in cases where the respondents are loyal to the brand-retailer-channel. Furthermore, given the low levels of actual purchase obtained in this study, it was impossible to make a connection with behaviour. There is thus a need to research the connections of CBBRCE beyond intention; future studies with global brands, such as Colgate toothpaste, could explore this connection, as well as measure other type of responses, such as approach and avoidance.

\section{References}

AAKER, D. A. 1991. Managing brand equity, New York, N.Y., Free Press.

AAKER, D. A. 1996. Building strong brands, Free Press New York.

AAKER, D. A. \& KELLER, K. L. 1990. Consumer evaluations of brand extensions. The Journal of Marketing, 54, 27.

AGHEKYAN-SIMONIAN, M., FORSYTHE, S., KWON, W. S. \& CHATTARAMAN, V. 2012. The role of product brand image and online store image on perceived risks and online purchase intentions for apparel. Journal of Retailing and Consumer Services, 19, 325-331.

AHMAD, A. \& THYAGARAJ, K. S. 2014. Brand Personality and Brand Equity Research: Past Developments and Future Directions. IUP Journal of Brand Management, 11, 1956.

AILAWADI, K. L. \& KELLER, K. L. 2004. Understanding retail branding: conceptual insights and research priorities. Journal of Retailing, 80, 331.

AILAWADI, K. L., LEHMANN, D. R. \& NESLIN, S. A. 2003. Revenue premium as an outcome measure of brand equity. Journal of Marketing, 67, 1.

ANDERSON, J. C. \& NARUS, J. A. 1990. A model of distributor firm and manufacturer firm working partnerships. the Journal of Marketing, 54, 42.

ANDERSON, N. H. 1971. Integration theory and attitude change. Psychological review, 78, 171.

ANDERSON, N. H. 1976. Equity judgments as information integration. Journal of personality and social psychology, 33, 291.

ANSARI, A., MELA, C. F. \& NESLIN, S. A. 2008. Customer Channel Migration. Journal of Marketing Research (JMR), 45, 60. 
ARMITAGE, C. J. \& CONNER, M. 2001. Eficacy of the theory of planned behaviour: A meta-analytic review. British Journal of Social Psychology, 40, 471.

ARNETT, D. B., LAVERIE, D. A. \& MEIERS, A. 2003. Developing parsimonious retailer equity indexes using partial least squares analysis: a method and applications. Journal of Retailing, 79, 161.

ARNETT, D. B., LAVERIE, D. A. \& WILCOX, J. B. 2010. A longitudinal examination of the effects of retailer-manufacturer brand alliances: The role of perceived fit. Journal of Marketing Management, 26, 5.

ATILGAN, E., AKSOY, S. \& AKINCI, S. 2005. Determinants of the brand equity: A verification approach in the beverage industry in Turkey. Marketing Intelligence \& Planning, 23, 237.

BALDAUF, A., CRAVENS, K. S. \& BINDER, G. 2003. Performance consequences of brand equity management: evidence from organizations in the value chain. Journal of product \& brand management, 12, 220.

BALDAUF, A., CRAVENS, K. S., DIAMANTOPOULOS, A. \& ZEUGNER-ROTH, K. P. 2009. The Impact of Product-Country Image and Marketing Efforts on RetailerPerceived Brand Equity: An Empirical Analysis. Journal of Retailing, 85, 437.

BICK, G. N. C. 2009. Increasing shareholder value through building Customer and Brand Equity. Journal of Marketing Management, 25, 117.

BRECKLER, S. J. \& WIGGINS, E. C. 1989. Affect versus evaluation in the structure of attitudes. Journal of Experimental Social Psychology, 25, 253-271.

BRODIE, R. J., GLYNN, M. S. \& VAN DURME, J. 2002. Towards a Theory of Marketplace Equity. Marketing Theory, 2, 5.

BUIL, I., DE CHERNATORY, L. \& MARTÍNEZ, E. 2008. A cross-national validation of the consumer-based brand equity scale. Journal of Product \& Brand Management, 17, 384.

CHATTOPADHYAY, T., SHIVANI, S. \& KRISHNAN, M. 2010. Marketing Mix Elements Influencing Brand Equity and Brand Choice. Vikalpa, 35, 67.

CHEN, A. C. H. 2001. Using free association to examine the relationship between the characteristics of brand associations and brand equity. Journal of Product \& Brand Management, 10, 439.

CHEN, X. 2010. Assessment of destination brand associations: An application of Associative Network Theory and network analysis methods. Clemson University.

CHIN, W. W. 1998. The partial least squares approach for structural equation modeling. In: MARCOULIDES, G. A. (ed.) Modern methods for business research. Methodology for business and management. Seventh ed. Nj: Lawrence Erlbaum Associates.

CHIN, W. W. 2010. Bootstrap cross-validation indices for PLS path model assessment. In: ESPOSITO VINZI, V., CHIN, W. W., HENSELER, J. \& WANG, H. (eds.) Handbook of partial least squares. First ed. Berlin: Springer.

CHOI, S. \& MATTILA, A. S. 2009. Perceived fairness of price differences across channels: the moderating role of price frame and norm perceptions. The Journal of Marketing Theory and Practice, 17, 37.

CHRISTODOULIDES, G. \& DE CHERNATONY, L. 2004. Dimensionalising on-and offline brands' composite equity. Journal of product \& brand management, 13, 168.

CHRISTODOULIDES, G. \& DE CHERNATONY, L. 2010. Consumer-based brand equity conceptualisation and measurement. International Journal of Market Research, 52, 43.

COBB-WALGREN, C. J., RUBLE, C. A. \& DONTHU, N. 1995. Brand equity, brand preference, and purchase intent. Journal of Advertising, 24, 25. 
COLLINS, A. M. \& LOFTUS, E. F. 1975. A spreading-activation theory of semantic processing. Psychological review, 82, 407.

D, M. 2015. Why does the-coca-cola taste so good at mcdonalds? [Online]. Available: http://www.mcdonalds.com/us/en/your_questions/our_food/why-does-the-coca-colataste-so-good-at-mcdonalds.html.

DABIJA, D.-C., SZENTESI, S. \& POP, N. A. 2014. A customer-oriented perspective on retail brand equity in the fashion industry. Dabija Dan-Cristian, Pop Nicolae Al., Szentesi Silviu, A Customer-Oriented Perspective on Retail Brand Equity in the Fashion Industry, Industria Textilă, 65, 37-46.

DAVIDSON, H. 1998. The next generation of brand measurement. Journal of Brand Management, 5, 430-439.

DAVIS, D. F. \& MENTZER, J. T. 2008. Relational Resources in Interorganizational Exchange: The Effects of Trade Equity and Brand Equity. Journal of Retailing, 84, 435.

DAWSON, J. A., FINDLAY, A. M. \& SPARKS, L. 2008. The retailing reader, Routledge Abingdon VA.

DAY, G. S. 1972. Evaluating Models of Attitude Structure. Journal of Marketing Research (JMR), 9, 279.

DEL RIO, A. B., VAZQUEZ, R. \& IGLESIAS, V. 2001. The effects of brand associations on consumer response. Journal of Consumer Marketing, 18, 410.

DENNIS, C., MORGAN, A., WRIGHT, L. T. \& JAYAWARDHENA, C. 2010. The influences of social e-shopping in enhancing young women's online shopping behaviour. Journal of Customer Behaviour, 9, 151.

DIETZ, J. 1997. Satisfaction: A Behavioral Perspective on the Consumer. Journal of Consumer Marketing, 14, 401.

FALK, R. F. \& MILLER, N. B. 1992. A primer for soft modeling, University of Akron Press.

FARQUHAR, P. H., HAN, J. Y. \& IJIRI, Y. 1991. Recognizing and measuring brand assets. Marketing Science Institute.

FRANK, M. J., COHEN, M. X. \& SANFEY, A. G. 2009. Multiple Systems in Decision Making A Neurocomputational Perspective. Current Directions in Psychological Science, 18, 73-77.

GARSVAITE, K. \& CARUANA, A. 2014. Do consumers of FMCGs seek brands with congruent personalities\&quest. Journal of Brand Management, 21, 485-494.

GREWAL, D., LEVY, M. \& LEHMANN, D. R. 2004. Retail branding and customer loyalty: an overview. Journal of retailing, 80, ix-xii.

GRÉGOIRE, Y. \& FISHER, R. J. 2006. The effects of relationship quality on customer retaliation. Marketing Letters, 17, 31.

HA, H. Y. 2009. Effects of Two Types of Service Quality on Brand Equity in China: The Moderating Roles of Satisfaction, Brand Associations, and Brand Loyalty. Seoul Journal of Business, 15, 59.

HAIGH, D. 1999. Understanding the financial value of brands. company report available at http://BrandFinance.com/eaaa.pdf.

HANANTO, A. 2006. Developing and Assessing the Reliability and Validity of an Alternative Scale to Measure Brand Equity. Social Science Research Network.

HATCH, M. J. \& SCHULTZ, M. 2010. Toward a theory of brand co-creation with implications for brand governance. Journal of Brand Management, 17, 590-604.

HERRMANN, A., HUBER, F., SHAO, A. T. \& BAO, Y. 2007. Building brand equity via product quality. Total quality management, 18, 531-544. 
HILLENBRAND, P., ALCAUTER, S., CERVANTES, J. \& BARRIOS, F. 2013. Better branding: brand names can influence consumer choice. Journal of Product \& Brand Management, 22, 300-308.

HILLIGSOE, S. 2009. Negotiation the Art of Reaching Agreement, Denmark, Torben Bystrup Jacobsen.

HOLBROOK, M. B. \& MOORE, W. L. 1981. Feature interactions in consumer judgments of verbal versus pictorial presentations. Journal of Consumer Research, 8, 103.

JANAKIRAMAN, R. \& NIRAJ, R. 2011. The Impact of Geographic Proximity on What to Buy, How to Buy, and Where to Buy: Evidence from High-Tech Durable Goods Market*. Decision Sciences, 42, 889.

JARA, M. 2009. «Retail Brand Equity: A PLS Approach. European Institute of Retailing and Services Studies NIAGARA FALLS : Canada.

JARA, M. \& CLIQUET, G. 2012. Retail brand equity: Conceptualization and measurement. Journal of Retailing and Consumer Services, 19, 140.

JINFENG, W. \& ZHILONG, T. 2009. The impact of selected store image dimensions on retailer equity: Evidence from 10 Chinese hypermarkets. Journal of Retailing and Consumer Services, 16, 486.

JONES, R. 2005. Finding sources of brand value: Developing a stakeholder model of brand equity. Journal of Brand Management, 13, 10.

JUAN BERISTAIN, J. \& ZORRILLA, P. 2011. The relationship between store image and store brand equity: A conceptual framework and evidence from hypermarkets. Journal of Retailing \& Consumer Services, 18, 562.

KAKATI, R. P. \& CHOUDHURY, S. 2013. Measuring Customer-Based Brand Equity Through Brand Building Blocks for Durables. IUP Journal of Brand Management, 10, 24-41.

KELLER, K. L. 1993. Conceptualizing, measuring, and managing customer-based brand equity. The Journal of Marketing, 57, 1.

KELLER, K. L. 2003. Brand Synthesis: The Multidimensionality of Brand Knowledge. Journal of Consumer Research, 29, 595.

KELLER, K. L. 2010. Brand equity management in a multichannel, multimedia retail environment. Journal of Interactive Marketing, 24, 58.

KELLER, K. L. \& LEHMANN, D. R. 2009. Assessing long-term brand potential. Journal of Brand Management, 17, 6-17.

KIM, W. G. \& KIM, H. B. 2004. Measuring customer-based restaurant brand equity. Cornell Hotel and Restaurant Administration Quarterly, 45, 115.

KIRK, C. P., RAY, I. \& WILSON, B. 2013. The impact of brand value on firm valuation: The moderating influence of firm type. Journal of Brand Management, 20, 488-500.

KUMAR, V., BOHLING, T. R. \& LADDA, R. N. 2003. Antecedents and consequences of relationship intention: Implications for transaction and relationship marketing. Industrial Marketing Management, 32, 667.

LEITCH, S. \& DAVENPORT, S. 2007. Corporate brands and social brands: Co-branding GM-free and UK supermarkets. International Studies of Management \& Organization, 37, 45-63.

LEONE, R. P., RAO, V. R., KELLER, K. L., LUO, A. M., MCALISTER, L. \& SRIVASTAVA, R. 2006. Linking Brand Equity to Customer Equity. Journal of Service Research, 9, 125.

LOW, G. S. \& LAMB JR, C. W. 2000. The measurement and dimensionality of brand associations. Journal of Product \& Brand Management, 9, 350.

MITCHELL, V. \& CHAUDHURY, A. 2014. Predicting retail brand extension strategy success: A consumer based model. Journal of Customer Behaviour, 13, 93-111. 
MOTAMENI, R. \& SHAHROKHI, M. 1998. Brand equity valuation: a global perspective. Journal of Product \& Brand Management, 7, 275.

NARUS, J. A. \& ANDERSON, J. C. 1986. Turn your industrial distributors into partners. Harvard business review, 64, 64.

NESLIN, S. A., GREWAL, D., LEGHORN, R., SHANKAR, V., TEERLING, M. L., THOMAS, J. S. \& VERHOEF, P. C. 2006. Challenges and Opportunities in Multichannel Customer Management. Journal of Service Research, 9(2), 95.

NETEMEYER, R. G., KRISHNAN, B., PULLIG, C., WANG, G., YAGCI, M., DEAN, D., RICKS, J. \& WIRTH, F. 2004. Developing and validating measures of facets of customer-based brand equity. Journal of Business Research, 57, 209.

PAPPU, R. \& QUESTER, P. 2006. Does customer satisfaction lead to improved brand equity? An empirical examination of two categories of retail brands. Journal of Product \& Brand Management, 15, 4.

PAPPU, R., QUESTER, P. G. \& COOKSEY, R. W. 2005. Consumer-based brand equity: improving the measurement -- empirical evidence. Journal of Product \& Brand Management, 14, 142.

PARK, C. W., JUN, S. Y. \& SHOCKER, A. D. 1996. Composite branding alliances: An investigation of extension and feedback effects. Journal of Marketing Research, 453466.

PRASAD, K. \& DEV, C. S. 2000. Managing hotel brand equity. Cornell Hotel and Restaurant Administration Quarterly, 41, 22.

RAO, A. R., QU, L. \& RUEKERT, R. W. 1999. Signaling unobservable product quality through a brand ally. Journal of Marketing Research, 36, 258.

RAO, A. R. \& RUEKERT, R. W. 1994. Brand alliances as signals of product quality. Sloan management review, 36, 87.

RASTOGI, P. \& SHARMA, R. 2015. Intrim Business Associates: taking on global consulting goliaths. Emerald Emerging Markets Case Studies, 5, 1-20.

RICHELIEU, A., PAWLOWSKI, T. \& BREUER, C. 2011. Football brand management: Minor league versus Champions League. Journal of Sponsorship, 4.

RINGLE, C. M., WENDE, S. \& BECKER, J.-M. 2014. SmartPLS 3. Hamburg.

ROWLEY, J. 2009. Online branding strategies of UK fashion retailers. Internet Research, 19, 348-369.

SHOCKER, A. D. \& WEITZ, B. 1988. A perspective on brand equity principles and issues. Defining, Measuring, and Managing Brand Equity, Report, 2.

SIMON, C. J. \& SULLIVAN, M. W. 1993. The measurement and determinants of brand equity: a financial approach. Marketing science, 12, 28.

SIMON, H. A. 1972. Theories of bounded rationality. Decision and organization, 1, 161.

SIMONIN, B. L. \& RUTH, J. A. 1998a. Is a Company Known by the Company It Keeps? Assessing the Spillover Effects of Brand Alliances on Consumer Brand Attitudes. Journal of Marketing Research (JMR), 35, 30.

SIMONIN, B. L. \& RUTH, J. A. 1998b. Is a company known by the company it keeps? Assessing the spillover effects of brand alliances on consumer brand attitudes. Journal of Marketing Research, 30.

SINHA, A., LESZECZYC, P. P., PAPPU, R., GREGORY, G. T. \& MURPHY, P. E. 2000. Measuring customer based brand equity: A survey-based methodology using hierarchical Bayes model. Australasian Marketing Journal (AMJ), 16, 3.

SINHA, A. \& PAPPU, R. Parcelling of the Sub-Components of Consumer-Based Brand Equity Using Factorial Survey: An Empirical Investigation in the New Zealand Consumer Electronics Sector. Proceedings, Australia New Zealand Marketing 
Academy Conference (ANZMAC), University of Otago, Dunedin,(December), 1998. 156.

SISSORS, J. \& BUMBA, L. 1996. Advertising Media Planning, Lincolnwood, IL, NTC Business Books.

SPRY, A., PAPPU, R. \& CORNWELL, T. B. 2011. Celebrity endorsement, brand credibility and brand equity. European Journal of Marketing, 45, 882.

SRIVASTAVA, R. K., SHERVANI, T. A. \& FAHEY, L. 1998. Market-Based Assets and Shareholder Value: A Framework for Analysis. Journal of Marketing, 62, 2.

SULLIVAN, U. Y. \& THOMAS, J. 2004. Customer migration: an empirical investigation across multiple channels. Arbeitspapier, Northwestern University.

THUY, N., DADZIE, C. \& DAVARI, A. 2013. Does brand equity mean brand equity? An empirical study of consumer based brand equity and financial based brand equity. AMA Summer Educators' Conference Proceedings, 24, 344-345.

TILL, B. D., BAACK, D. \& WATERMAN, B. 2011. Strategic brand association maps: developing brand insight. Journal of Product \& Brand Management, 20, 92.

TRAN, Q. 2006. Retailers' perceptions of product brand equity: an empirical study of Vietnamese independent grocers. Theses, 46.

TRAN, Q. \& COX, C. 2009. Building brand equity between manufacturers and retailers. Business-To-Business Brand Management: Theory, Research and Executivecase Study Exercises (Advances in Business Marketing and Purchasing, Volume 15), Emerald Group Publishing Limited, 15, 115.

TROUTMAN, C. M. \& SHANTEAU, J. 1976. Do consumers evaluate products by adding or averaging attribute information? Journal of Consumer Research, 3, 101.

TVERSKY, A. 1977. Features of similarity. Psychological review, 84, 327.

UGGLA, H. 2004. The brand association base: A conceptual model for strategically leveraging partner brand equity. Journal of Brand Management, 12, 105.

VARADARAJAN, P. R. \& YADAV, M. S. 2002. Marketing Strategy and the Internet: An Organizing Framework. Journal of the Academy of Marketing Science, 30, 296.

VAZQUEZ, R., RÍO, A. B. \& IGLESIAS, V. 2002. Consumer-based brand equity: development and validation of a measurement instrument. Journal of Marketing management, 18, 27.

WANG, Y. C., HSU, K. C., HSU, S. H. \& HSIEH, P. A. J. J. 2011. Constructing an index for brand equity: a hospital example. The Service Industries Journal, 31, 311.

WASHBURN, J. H. \& PLANK, R. E. 2002a. Measuring brand equity: An evaluation of a consumer-based brand equity scale. Journal of Marketing Theory and Practice, 10, 46.

WASHBURN, J. H. \& PLANK, R. E. 2002b. Measuring brand equity: an evaluation of a consumer-based brand equity scale. Journal of Marketing Theory \& Practice, 10, 46.

WASHBURN, J. H., TILL, B. D. \& PRILUCK, R. 2004. Brand alliance and customer-based brand-equity effects. Psychology and Marketing, 21, 487.

WRIGHT, O. \& CLARKE, P. 2014. A Case Study Synthesis of Co-branding, Retailing and Franchising. Asian Journal of Marketing, 8, 71-85.

YASIN, N. M., NOOR, M. N. \& MOHAMAD, O. 2007. Does image of country-of-origin matter to brand equity? Journal of Product \& Brand Management, 16, 38.

YOO, B. \& DONTHU, N. Developing and validating a consumer-based overall brand equity scale for Americans and Koreans: An extension of Aaker's and Keller's conceptualizations. AMA Summer Educators Conference, Chicago, 1997. 
YOO, B. \& DONTHU, N. 2001a. Developing a scale to measure the perceived quality of an Internet shopping site (SITEQUAL). Quarterly Journal of Electronic Commerce, 2, 31.

YOO, B. \& DONTHU, N. 2001b. Developing and validating a multidimensional consumerbased brand equity scale. Journal of business research, 52, 1.

YOO, B. \& DONTHU, N. 2002. Testing cross-cultural invariance of the brand equity creation process. Journal of Product \& Brand Management, 11, 380-398.

YOO, B., DONTHU, N. \& LEE, S. 2000. An examination of selected marketing mix elements and brand equity. Journal of the Academy of Marketing Science, 28, 195.

ZEUGNER ROTH, K. P., DIAMANTOPOULOS, A. \& MONTESINOS, M. Á. 2008. Home country image, country brand equity and consumers' product preferences: an empirical study. Management International Review, 48, 577.

ZHUANG, G. \& ZHOU, N. 2004. The relationship between power and dependence in marketing channels: A Chinese perspective. European Journal of Marketing, 38, 675. 
Figure 1

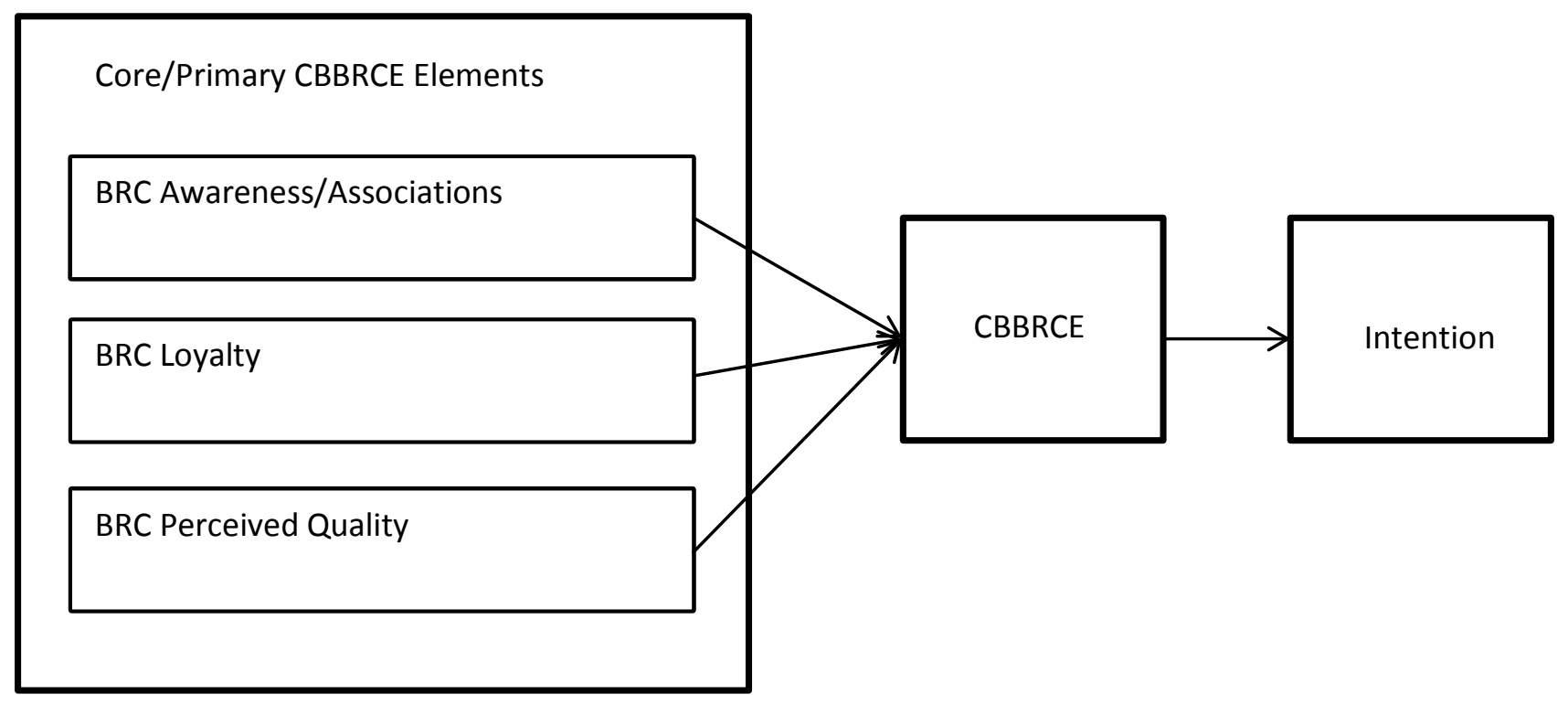


Table 1 - Studies that have used Aaker and Keller's Brand Equity Dimensions

\begin{tabular}{|c|c|c|c|c|}
\hline Author & $\begin{array}{l}\text { Brand/Name } \\
\text { Awareness }\end{array}$ & $\begin{array}{l}\text { Brand/Retailer } \\
\text { Associations } \\
\text { (Image) }\end{array}$ & $\begin{array}{l}\text { Perceived/Service } \\
\text { Quality }\end{array}$ & $\begin{array}{l}\text { Brand/Store } \\
\text { Loyalty }\end{array}$ \\
\hline $\begin{array}{l}\text { Shocker and } \\
\text { Weitz (1988) }\end{array}$ & No & Yes & No & Yes \\
\hline Aaker (1991) & Yes & Yes & Yes & Yes \\
\hline Keller (1993) & Yes & Yes & No & No \\
\hline $\begin{array}{l}\text { Cobb-Walgren } \\
\text { et al., (1995) }\end{array}$ & Yes & Yes & Yes & Yes \\
\hline $\begin{array}{l}\text { Sinha and } \\
\text { Pappu, (1998) }\end{array}$ & Yes & Yes & Yes & Yes \\
\hline $\begin{array}{l}\text { Sinha et al., } \\
\text { (2000) }\end{array}$ & Yes & Yes & Yes & Yes \\
\hline $\begin{array}{l}\text { Del Rio et al., } \\
\text { (2001) }\end{array}$ & No & Yes & No & No \\
\hline $\begin{array}{l}\text { Yoo et al., } \\
\text { (2000) }\end{array}$ & \multicolumn{2}{|l|}{ Yes (unified) } & Yes & Yes \\
\hline $\begin{array}{l}\text { Yoo and } \\
\text { Donthu, (2001a) }\end{array}$ & \multicolumn{2}{|l|}{ Yes (unified) } & Yes & Yes \\
\hline $\begin{array}{l}\text { Washburn and } \\
\text { Plank, (2002a) }\end{array}$ & \multicolumn{2}{|l|}{ Yes (unified) } & Yes & Yes \\
\hline $\begin{array}{l}\text { Arnett et al., } \\
\text { (2003) }\end{array}$ & Yes & Yes & Yes & Yes \\
\hline $\begin{array}{l}\text { Netemeyer et } \\
\text { al., (2004) }\end{array}$ & Yes & Yes & Yes & No \\
\hline $\begin{array}{l}\text { Kim and Kim, } \\
\text { (2004) }\end{array}$ & Yes & Yes & Yes & Yes \\
\hline $\begin{array}{l}\text { Pappu et al., } \\
\text { (2005) }\end{array}$ & Yes & Yes & Yes & Yes \\
\hline $\begin{array}{l}\text { Atilgan et al., } \\
\text { (2005) }\end{array}$ & Yes & Yes & Yes & Yes \\
\hline $\begin{array}{l}\text { Pappu and } \\
\text { Quester, (2006) }\end{array}$ & Yes & Yes & Yes & Yes \\
\hline Hananto, (2006) & Yes & Yes & Yes & Yes \\
\hline $\begin{array}{l}\text { Zeugner Roth et } \\
\text { al., (2008) }\end{array}$ & \multicolumn{2}{|l|}{ Yes(unified) } & Yes & Yes \\
\hline $\begin{array}{l}\text { Buil et al., } \\
\text { (2008) }\end{array}$ & Yes & Yes & Yes & Yes \\
\hline $\begin{array}{l}\text { Jinfeng and } \\
\text { Zhilong, (2009) }\end{array}$ & Yes & Yes & Yes & Yes \\
\hline На, (2009) & & Yes & Yes & Yes \\
\hline Jara, (2009) & Yes & Yes & Yes & No \\
\hline $\begin{array}{l}\text { Chattopadhyay } \\
\text { et al., (2010) }\end{array}$ & Yes & Yes & Yes & No \\
\hline $\begin{array}{l}\text { Wang et al., } \\
\text { (2011) }\end{array}$ & Yes & Yes & Yes & Yes \\
\hline $\begin{array}{l}\text { Spry et al., } \\
\text { (2011) }\end{array}$ & Yes & Yes & Yes & Yes \\
\hline
\end{tabular}




\begin{tabular}{|c|c|c|c|c|}
\hline $\begin{array}{l}\text { Juan Beristain } \\
\text { and Zorrilla, } \\
\text { (2011) }\end{array}$ & \multicolumn{2}{|c|}{ Yes (Unified) } & Yes & Yes \\
\hline $\begin{array}{l}\text { Jara and Cliquet, } \\
\text { (2012) }\end{array}$ & Yes & Yes & Yes & Yes \\
\hline
\end{tabular}


Table 2:

\begin{tabular}{|l|l|c|l|}
\hline Construct & Source & $\begin{array}{c}\text { No. of } \\
\text { Items }\end{array}$ & Scale \\
\hline $\begin{array}{l}\text { Awareness/Associ } \\
\text { ations }\end{array}$ & $\begin{array}{l}\text { (Yoo, Donthu 2001) (Srull 1984) (Alba, Hutchinson 1987) } \\
\text { (Rossiter, Percy 1987) }\end{array}$ & 4 & Likert \\
\hline Quality & (Yoo, Donthu 2001) (Dodds, Monroe et al. 1991) & 2 & Likert \\
\hline Loyalty & (Yoo, Donthu 2001) (Beatty, Kahle 1988) & 3 & Likert \\
\hline CBBRCE & (Yoo, Donthu 2001) & 4 & Likert \\
\hline Intention & (Ajzen 1991) (Francis, Eccles et al. 2004) & 3 & Likert \\
\hline
\end{tabular}


Table 3: Demographic Statistics

\begin{tabular}{|c|c|c|c|}
\hline & Drugstore & Internet & Multichanne \\
\hline \multicolumn{4}{|l|}{ Self classification } \\
\hline Unaware & 35.7 & 44.9 & 39.2 \\
\hline Aware & 62.5 & 49.0 & 56.9 \\
\hline \multicolumn{4}{|l|}{ Using 1-15w } \\
\hline Using $>16 \mathrm{w}$ & & & 2.0 \\
\hline Used in the past & 1.8 & 6.1 & 2.0 \\
\hline Channel Familiarity & Drugstore & Internet & Multichanne \\
\hline Uses Channel & \begin{tabular}{|l|}
50.0 \\
\end{tabular} & 59.6 & 65.4 \\
\hline Do not uses Channel & 50.0 & 40.4 & 34.6 \\
\hline Marital Status & Drugstore & Internet & Multichanne \\
\hline Married/ living with a partner & 42.9 & 47.4 & 54.2 \\
\hline Widowed & & 1.8 & 1.7 \\
\hline Divorced & 3.2 & 3.5 & \\
\hline Separated & 3.2 & 1.8 & \\
\hline Single/ Never married & 50.8 & 45.6 & 44.1 \\
\hline Academic Qualifications & Drugstore & Internet & Multichanne \\
\hline High school or less & 27.1 & 30.8 & 41.4 \\
\hline Some college & 27.1 & 26.9 & 24.1 \\
\hline Bachelors degree & 20.3 & 15.4 & 12.1 \\
\hline Graduate or professional degree & 25.4 & 26.9 & 22.4 \\
\hline Working Status & Drugstore & Internet & Multichanne \\
\hline Not working & 1.7 & 5.6 & 3.6 \\
\hline Part-time (> 20 hrs/week) & 18.3 & 5.6 & 10.7 \\
\hline $3 / 4$ time $(20-31$ hrs/week) & & & 1.8 \\
\hline Full time (32-40hrs/week) & 50.0 & 64.8 & 55.4 \\
\hline Self Employed & 11.7 & 9.3 & 8.9 \\
\hline Student & 13.3 & 11.1 & 17.9 \\
\hline Employee & 5.0 & 3.7 & \\
\hline Retired & & & 1.8 \\
\hline \multicolumn{4}{|l|}{ Other } \\
\hline Income & Drugstore & Internet & Multichanne \\
\hline Less than $£ 9,999$ & 23.7 & 14.8 & 14.3 \\
\hline$£ 10,000-£ 29,999$ & 27.1 & 55.6 & 37.5 \\
\hline$£ 30,000-£ 49,999$ & 27.1 & 22.2 & 30.4 \\
\hline$£ 50,000-£ 69,999$ & 10.2 & 5.6 & 10.7 \\
\hline$£ 70,000-£ 89,999$ & 5.1 & 1.9 & 1.8 \\
\hline$£ 90,000$ and more & 6.8 & .0 & 5.4 \\
\hline Number of Children & Drugstore & Internet & Multichanne \\
\hline 0 & 56.5 & 63.2 & 44.2 \\
\hline 1 & 23.9 & 10.5 & 23.3 \\
\hline 2 & 13.0 & 18.4 & 18.6 \\
\hline 3 & 4.3 & 7.9 & 14.0 \\
\hline 4 & 2.2 & & \\
\hline \multicolumn{4}{|l|}{5} \\
\hline Household Composition & Drugstore & Internet & Multichanne \\
\hline Living Alone & 24.1 & 26.8 & 25.0 \\
\hline Living with Partner & 24.1 & 32.1 & 19.6 \\
\hline Living with children & & 1.8 & 7.1 \\
\hline Living with partner and children & 25.9 & 28.6 & 32.1 \\
\hline Living with parents & 25.9 & 10.7 & 16.1 \\
\hline Age & Drugstore & Internet & Multichanne \\
\hline Average & 31 & 32 & 31 \\
\hline
\end{tabular}




\section{Figure 2}

\section{Drugstore}

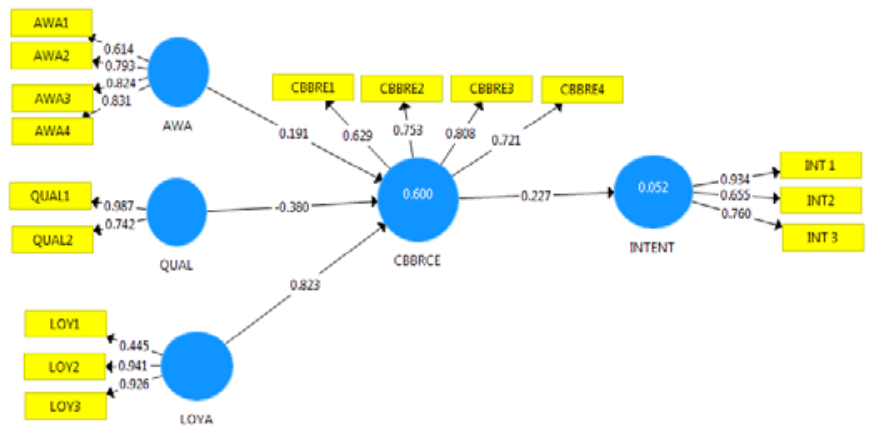

Internet

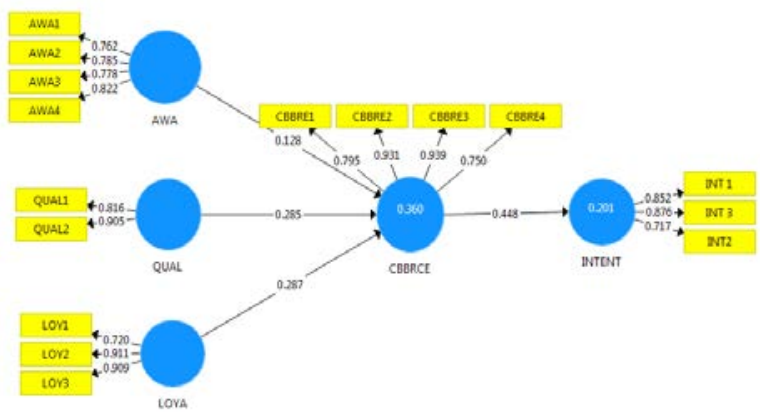

Multi-channel

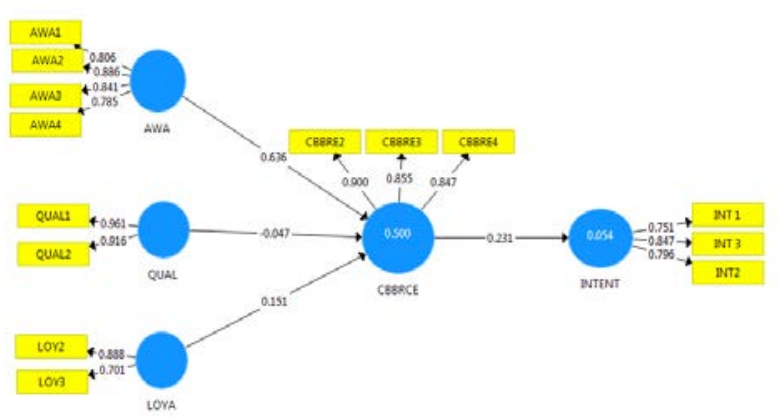




\section{Table 4}

\begin{tabular}{|c|c|c|c|c|c|c|c|c|c|}
\hline \multirow[b]{2}{*}{ Construct } & \multicolumn{2}{|r|}{ Drugstore } & \multirow[b]{2}{*}{ Average variance } & \multicolumn{2}{|r|}{ Internet } & \multirow[b]{2}{*}{ Average variance } & \multicolumn{3}{|c|}{ Multi-channel } \\
\hline & Loading & Composite & & Loading & Composite & & Loading & Composite & Average variance \\
\hline & & reliability & extracted & & reliability & extracted & & reliability & extracted \\
\hline & & & AVE & & & AVE & & & AVE \\
\hline Awareness/Associations & & 0,852 & & & 0,867 & 0,619 & & 0,899 & 0,689 \\
\hline AWA 1 & 0,614 & & & 0,762 & & & 0,806 & & \\
\hline AWA2 & 0,793 & & & 0,785 & & & 0,886 & & \\
\hline AWA3 & 0,824 & & & 0,778 & & & 0,841 & & \\
\hline AWA4 & 0,831 & & & 0,822 & & & 0,785 & & \\
\hline Quality & & 0,863 & & & 0,852 & 0,743 & & 0,936 & 0,881 \\
\hline QUAL1 & 0,987 & & & 0,816 & & & 0,961 & & \\
\hline QUAL2 & 0,742 & & & 0,905 & & & 0,916 & & \\
\hline \begin{tabular}{|l} 
Loyalty \\
\end{tabular} & & 0,835 & & & 0,886 & 0,724 & & 0,778 & 0,64 \\
\hline LOY1 & 0,445 & & & 0,72 & & & & & \\
\hline LOY2 & 0,941 & & & 0,911 & & & 0,888 & & \\
\hline LOY3 & 0,926 & & & 0,909 & & & 0,701 & & \\
\hline CBBRCE & & 0,82 & & & 0,917 & 0,735 & & 0,901 & 0,753 \\
\hline CBBRCE1 & 0,629 & & & 0,795 & & & & & \\
\hline CBBRCE2 & 0,753 & & & 0,931 & & & 0,9 & & \\
\hline CBBRCE3 & 0,808 & & & 0,939 & & & 0,855 & & \\
\hline CBBRCE4 & 0,721 & & & 0,75 & & & 0,847 & & \\
\hline Intention & & 0,831 & & & 0,858 & 0,669 & & 0,841 & 0,638 \\
\hline INT1 & 0,934 & & & 0,852 & & & 0,751 & & \\
\hline INT2 & 0,655 & & & 0,876 & & & 0,796 & & \\
\hline INT3 & 0,76 & & & 0,717 & & & 0,847 & & \\
\hline
\end{tabular}


Table 5

\begin{tabular}{|l|c|c|c|c|c|}
\hline \multicolumn{7}{|c|}{ Drugstore } \\
\hline \multirow{2}{*}{ AWA } & AWA & CBBRCE & INTENT & LOY & QUAL \\
\cline { 2 - 6 } CBBRCE & $\mathbf{0 , 8 3 1}$ & & & & \\
\hline INTENT & 0,745 & $\mathbf{0 , 7 7 9}$ & & & \\
\hline LOY & 0,448 & 0,238 & $\mathbf{0 , 7 9 8}$ & & \\
\hline QUAL & 0,634 & 0,542 & 0,526 & $\mathbf{0 , 7 1}$ & \\
\hline
\end{tabular}

\begin{tabular}{|l|c|c|c|c|c|}
\hline \multicolumn{7}{|c|}{ Internet } \\
\hline \multirow{2}{*}{ AWA } & AWA & CBBRCE & INTENT & LOY & QUAL \\
\cline { 2 - 6 } CBBRCE & $\mathbf{0 , 7 8 7}$ & & & & \\
\hline INTENT & 0,484 & $\mathbf{0 , 8 5 8}$ & & & \\
\hline LOY & 0,312 & 0,446 & $\mathbf{0 , 8 1 8}$ & & \\
\hline QUAL & 0,638 & 0,524 & 0,446 & $\mathbf{0 , 8 5 1}$ & \\
\hline
\end{tabular}

Multi-channel

\begin{tabular}{|l|c|c|c|c|c|}
\hline \multicolumn{7}{|c|}{ Multi-channel } \\
\hline \multirow{2}{*}{ AWA } & AWA & CBBRCE & INTENT & LOY & QUAL \\
\cline { 2 - 6 } & $\mathbf{0 , 8 3}$ & & & & \\
\hline CBBRCE & 0,701 & $\mathbf{0 , 8 6 7}$ & & & \\
\hline INTENT & 0,445 & 0,231 & $\mathbf{0 , 7 9 9}$ & & \\
\hline LOY & 0,632 & 0,514 & 0,497 & $\mathbf{0 , 8}$ & \\
\hline QUAL & 0,662 & 0,499 & 0,452 & 0,823 & $\mathbf{0 , 9 3 8}$ \\
\hline
\end{tabular}


Table 6

\begin{tabular}{|c|c|c|c|c|c|}
\hline & & \multicolumn{4}{|c|}{ Drugstore } \\
\hline & AWA & CBBRCE & INTENT & LOY & QUAL \\
\hline AWA1 & 0,614 & 0,084 & 0,319 & 0,217 & 0,377 \\
\hline AWA2 & 0,793 & 0,219 & 0,260 & 0,211 & 0,107 \\
\hline AWA3 & 0,824 & 0,248 & 0,186 & 0,155 & 0,079 \\
\hline AWA4 & 0,831 & 0,294 & 0,156 & 0,040 & $-0,076$ \\
\hline CBBRCE1 & 0,142 & 0,629 & 0,152 & 0,533 & 0,226 \\
\hline CBBRCE2 & 0,245 & 0,753 & 0,201 & 0,392 & $-0,083$ \\
\hline CBBRCE3 & 0,283 & 0,808 & 0,167 & 0,525 & $-0,037$ \\
\hline CBBRCE4 & 0,197 & 0,721 & 0,147 & 0,517 & 0,011 \\
\hline INT1 & 0,310 & 0,253 & 0,934 & 0,344 & 0,334 \\
\hline INT3 & 0,056 & 0,120 & 0,760 & 0,241 & 0,169 \\
\hline INT2 & 0,180 & 0,034 & 0,655 & 0,093 & 0,093 \\
\hline LOY1 & 0,171 & 0,133 & 0,242 & 0,445 & 0,305 \\
\hline LOY2 & 0,149 & 0,640 & 0,382 & 0,941 & 0,454 \\
\hline LOY3 & 0,149 & 0,651 & 0,237 & 0,926 & 0,424 \\
\hline QUAL1 & 0,092 & 0,033 & 0,348 & 0,479 & 0,987 \\
\hline \multirow[t]{3}{*}{ QUAL2 } & $-0,010$ & 0,008 & 0,046 & 0,335 & 0,742 \\
\hline & & \multicolumn{4}{|c|}{ Internet } \\
\hline & AWA & CBBRCE & INTENT & LOY & QUAL \\
\hline AWA1 & 0,762 & 0,438 & 0,239 & 0,574 & 0,701 \\
\hline AWA2 & 0,785 & 0,315 & 0,176 & 0,362 & 0,465 \\
\hline AWA3 & 0,778 & 0,316 & 0,221 & 0,428 & 0,276 \\
\hline AWA4 & 0,822 & 0,421 & 0,322 & 0,587 & 0,416 \\
\hline CBBRCE1 & 0,337 & 0,795 & 0,328 & 0,365 & 0,282 \\
\hline CBBRCE2 & 0,465 & 0,931 & 0,477 & 0,521 & 0,512 \\
\hline CBBRCE3 & 0,485 & 0,939 & 0,453 & 0,536 & 0,545 \\
\hline CBBRCE4 & 0,342 & 0,750 & 0,212 & 0,324 & 0,394 \\
\hline INT1 & 0,296 & 0,416 & 0,852 & 0,326 & 0,100 \\
\hline INT3 & 0,254 & 0,407 & 0,876 & 0,448 & 0,196 \\
\hline INT2 & 0,204 & 0,234 & 0,717 & 0,315 & 0,097 \\
\hline LOY1 & 0,277 & 0,334 & 0,338 & 0,720 & 0,386 \\
\hline LOY2 & 0,635 & 0,480 & 0,463 & 0,911 & 0,524 \\
\hline LOY3 & 0,649 & 0,504 & 0,340 & 0,909 & 0,483 \\
\hline QUAL1 & 0,515 & 0,374 & 0,079 & 0,484 & 0,816 \\
\hline \multirow[t]{3}{*}{ QUAL2 } & 0,541 & 0,509 & 0,189 & 0,472 & 0,905 \\
\hline & & \multicolumn{3}{|c|}{ Multi-channel } & \\
\hline & AWA & CBBRCE & INTENT & LOY & QUAL \\
\hline AWA1 & 0,766 & 0,442 & 0,239 & 0,619 & 0,7 \\
\hline AWA2 & 0,796 & 0,358 & 0,181 & 0,380 & 0,468 \\
\hline AWA3 & 0,763 & 0,275 & 0,220 & 0,485 & 0,274 \\
\hline AWA4 & 0,818 & 0,433 & 0,320 & 0,610 & 0,414 \\
\hline CBBRCE2 & 0,470 & 0,945 & 0,482 & 0,521 & 0,516 \\
\hline CBBRCE3 & 0,487 & 0,947 & 0,455 & 0,534 & 0,545 \\
\hline CBBRCE4 & 0,342 & 0,769 & 0,214 & 0,312 & 0,399 \\
\hline INT1 & 0,296 & 0,414 & 0,852 & 0,307 & 0,105 \\
\hline INT3 & 0,255 & 0,425 & 0,883 & 0,422 & 0,199 \\
\hline INT2 & 0,197 & 0,212 & 0,703 & 0,323 & 0,092 \\
\hline LOY2 & 0,633 & 0,494 & 0,462 & 0,939 & 0,522 \\
\hline LOY3 & 0,644 & 0,498 & 0,341 & 0,940 & 0,481 \\
\hline QUAL1 & 0,515 & 0,371 & 0,076 & 0,483 & 0,801 \\
\hline QUAL2 & 0,549 & 0,554 & 0,193 & 0,451 & 0,916 \\
\hline
\end{tabular}


Table 7

\begin{tabular}{|l|c|}
\hline Dependent Construct & $\mathbf{R}^{\mathbf{2}}$ \\
\hline Drugstore & \\
\hline CBBRCE & 0,6 \\
\hline Intention & 0,052 \\
\hline Internet & \\
\hline CBBRCE & 0,36 \\
\hline Intention & 0,201 \\
\hline Multi-channel & \\
\hline CBBRCE & 0,5 \\
\hline Intention & 0,054 \\
\hline
\end{tabular}

\section{Table 8}

\begin{tabular}{l||c|c|c|}
\hline Drugstore & & \\
\hline Path & Path coefficient & T statistic & Sign \\
\hline AWA -> CBBRCE & 0,191 & 1,839 & \\
CBBRCE -> INTENT & 0,227 & 1,048 & \\
\hline LOY -> CBBRCE & 0,823 & 7,166 & $* * *$ \\
\hline QUAL ->CBBRCE & $-0,380$ & 1,995 & $* *$ \\
\hline
\end{tabular}

\begin{tabular}{|l|c|c|c|}
\hline Internet & \multicolumn{3}{l|}{} \\
\hline Path & Path coefficient & T statistic & \multicolumn{1}{l|}{ Sign } \\
\hline AWA -> CBBRCE & 0,128 & 0,668 & \\
CBBRCE -> INTENT & 0,448 & 4,871 & $* * *$ \\
LOY -> CBBRCE & 0,287 & 1,782 & \\
\hline QUAL ->CBBRCE & 0,285 & 2,117 & $* * *$ \\
\hline
\end{tabular}

Multi-channel

\begin{tabular}{|l|c|c|c|}
\hline Path & Path coefficient & T statistic & Sign \\
\hline AWA -> CBBRCE & 0,636 & 5,368 & $* * *$ \\
\hline CBBRCE -> INTENT & 0,231 & 2,193 & $* * *$ \\
\hline LOY -> CBBRCE & 0,151 & 0,864 & \\
\hline QUAL ->CBBRCE & $-0,047$ & 0,305 & \\
\hline
\end{tabular}

$* \quad=90 \%$ significance $\mathrm{t}$-value $=1.64$

$* *=95 \%$ significance $\mathrm{t}$-value $=1.96$

$* * *=99 \%$ significance $\mathrm{t}$-value $=2.58$ 


\section{Appendix A: Proposed CBBRE items}

\section{CBBRCE Awareness/associations dimension:}

I can recognize brand $\mathrm{X}$ in retailer $\mathrm{Y}$ and Channel $\mathrm{Z}$ among other competing brands and retailers.

I am aware of brand $\mathrm{X}$ in retailer $\mathrm{Y}$ and Channel $\mathrm{Z}$

Some characteristics of brand $\mathrm{X}$ in retailer $\mathrm{Y}$ and Channel $\mathrm{Z}$ come to my mind quickly.

I can quickly recall the symbol or logo of brand X.

I can quickly recall the symbol or logo of retailer $\mathrm{X}$

I have difficulty in imagining brand $\mathrm{X}$ in retailer $\mathrm{X}$ and Channel $\mathrm{Z}$ in my mind.

\section{CBBRCE Loyalty dimension:}

I consider myself to be loyal to brand $\mathrm{X}$ sold in retailer $\mathrm{Y}$ and Channel $\mathrm{Z}$

Brand $\mathrm{X}$ in retailer $\mathrm{Y}$ and Channel $\mathrm{Z}$ would be my first choice.

I will not buy other brands if brand $\mathrm{X}$ is available at retailer $\mathrm{Y}$ and Channel $\mathrm{Z}$.

\section{CBBRCE Perceived quality dimension:}

The likely quality of brand $\mathrm{X}$ in Retailer $\mathrm{Y}$ and Channel $\mathrm{Z}$ is extremely high.

The likelihood that brand $\mathrm{X}$ in Retailer $\mathrm{Y}$ and Channel $\mathrm{Z}$ would be functional is very high.

\section{Four-item Overall CBBRCE:}

It makes sense to buy brand $\mathrm{X}$ in Retailer $\mathrm{Y}$ and Channel $\mathrm{Z}$ instead of any other brand-retailerchannel, even if they are the same.

Even if another brand-retailer-channel has the same features as brand $\mathrm{X}$ in retailer $\mathrm{Y}$, I would prefer to buy brand $\mathrm{X}$ in retailer $\mathrm{Y}$ and Channel $\mathrm{Z}$. 
If there is another brand-retailer as good as brand $\mathrm{X}$ in retailer $\mathrm{Y}$ and channel $\mathrm{Z}$, I prefer to buy brand $\mathrm{X}$ in retailer $\mathrm{Y}$ and Channel $\mathrm{Z}$.

If another brand-retailer is not different from brand $\mathrm{X}$ in retailer $\mathrm{Y}$ and channel $\mathrm{Z}$ in any way, it seems smarter to purchase brand $\mathrm{X}$ in retailer $\mathrm{Y}$ and channel $\mathrm{Z}$.

\section{Appendix B: Survey questions used to measure CBBRCE in the study.}

\begin{tabular}{|c|c|c|c|c|c|c|}
\hline I consider myself to be loyal to Regaine in Boots web page & $\begin{array}{l}\text { Strongly } \\
\text { disagree }\end{array}$ & 1 & 2 & 3 & 4 & 5 Strongly agree \\
\hline Regaine in Boots webpage would be my first choice. & $\begin{array}{l}\text { Strongly } \\
\text { disagree }\end{array}$ & 1 & 2 & 3 & 4 & 5 Strongly agree \\
\hline I will not buy other brands if Regaine is available at Boots web page & $\begin{array}{l}\text { Strongly } \\
\text { disagree }\end{array}$ & 1 & 2 & 3 & 4 & 5 Strongly agree \\
\hline The expected quality of Regaine in Boots web page is extremely high. & $\begin{array}{l}\text { Strongly } \\
\text { disagree }\end{array}$ & 1 & 2 & 3 & 4 & 5 Strongly agree \\
\hline $\begin{array}{l}\text { The likelihood that Regaine purchased in Boots web page has all its } \\
\text { therapeutic properties is very high. }\end{array}$ & $\begin{array}{l}\text { Strongly } \\
\text { disagree }\end{array}$ & 1 & 2 & 3 & 4 & 5 Strongly agree \\
\hline $\begin{array}{l}\text { I can recognize Regaine in Boots website among other competing } \\
\text { brands, retailers and channels. }\end{array}$ & $\begin{array}{l}\text { Strongly } \\
\text { disagree }\end{array}$ & 1 & 2 & 3 & 4 & 5 Strong \\
\hline sold on Boots web page & $\begin{array}{l}\text { Strongly } \\
\text { disagree }\end{array}$ & 1 & 2 & 3 & 4 & 5 Stron \\
\hline $\begin{array}{l}\text { If I think about a Package/Bottle of Regaine in Boots web page, it } \\
\text { comes to my mind quickly. }\end{array}$ & $\begin{array}{l}\text { Strongly } \\
\text { disagree }\end{array}$ & 1 & 2 & 3 & 4 & 5 Strongly agree \\
\hline I can quickly recall the symbol or logo of Regaine. & Strc & 1 & 2 & 3 & 4 & 5 Strongly agree \\
\hline I can quickly recall the symbol or logo of Boots. & $\begin{array}{l}\text { Strongly } \\
\text { disagree }\end{array}$ & 1 & 2 & 3 & 4 & 5 Strongly agree \\
\hline I have difficulty in imagining Regaine in Boots web page in my mind. & $\begin{array}{l}\text { Strongly } \\
\text { disagree }\end{array}$ & 1 & 2 & 3 & 4 & 5 Strongly agree \\
\hline $\begin{array}{l}\text { It makes sense to buy Regaine in Boots web page instead of any } \\
\text { other brand-retailer-channel, even if they are the same. }\end{array}$ & $\begin{array}{l}\text { Strongly } \\
\text { disagree }\end{array}$ & 1 & 2 & 3 & 4 & 5 Strongly agree \\
\hline $\begin{array}{l}\text { Even if another brand-retailer-channel has the same features as } \\
\text { Regaine in Boots web page, I would prefer to buy Regaine in Boots } \\
\text { webpage. }\end{array}$ & $\begin{array}{l}\text { Strongly } \\
\text { disagree }\end{array}$ & 1 & 2 & 3 & 4 & 5 Stron \\
\hline $\begin{array}{l}\text { If there is another brand-retailer-channel as good as Regaine in } \\
\text { Boots web page, I prefer to buy Regaine in Boots webpage. }\end{array}$ & $\begin{array}{l}\text { Strongly } \\
\text { disagree }\end{array}$ & 1 & 2 & 3 & 4 & ly agree \\
\hline $\begin{array}{l}\text { If another brand-retailer-channel is not different from Regaine in } \\
\text { Boots Internet Web page in any way, it seems smarter to shop for } \\
\text { Regaine in Boots webpage. }\end{array}$ & $\begin{array}{l}\text { Strongly } \\
\text { disagree }\end{array}$ & 1 & 2 & 3 & 4 & ree \\
\hline
\end{tabular}

